\title{
Projektarbejde på nettet - sådan da
}

\author{
Simon B. Heilesen \\ Lektor, mag.art. \\ Institut for Kommunikation, Journalistik og Datalogi \\ Roskilde Universitetscenter \\ simonhei@ruc.dk \\ http://www.ruc.dk/ simonhei
}

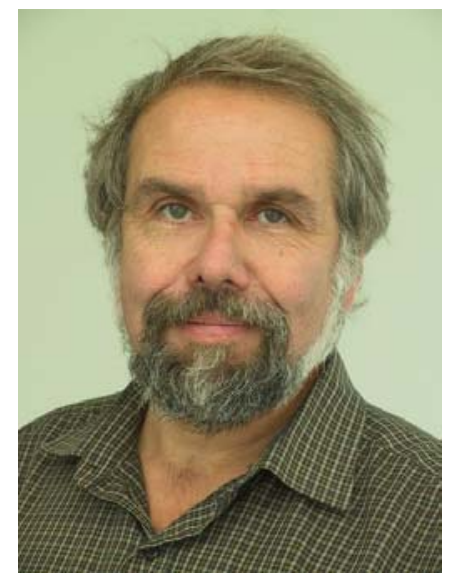

Simon Heilesen er lektor i Netmedier ved Kommunikationsuddannelsen på RUC og medarbejder ved den åbne og delvis netbaserede uddannelse Master i Computer-mediated Communication. Har skrevet forskellige artikler om netbaseret uddannelse og samarbejde. Medlem af UNEV's ekspertgruppe. Medlem af styregruppen for RUC's Portal-projekt (IKToprustning). Leder af Center for Viden og Design i Nye Medier på Institut VII, RUC.

Problemorienteret projektarbejde udført af grupper af studerende er en udbredt studieform på Roskilde Universitetscenter og Aalborg Universitet, og den også har vundet indpas en del andre steder. Som alt andet projektarbejde stiller den store krav til deltagernes evne til at koordinere, samarbejde og dele viden. De følgende sider handler om erfaringerne med at overføre denne arbejdsform til nettet i forbindelse med en åben uddannelse ved Roskilde Universitetscenter: Master i Computer-mediated Communication (MCC). Efter en kort beskrivelse af MCC-undervisningsformen vil jeg redegøre for nogle af de faktorer, som spiller ind på en remediering af projektarbejdet til nettet, og afslutningsvis vil jeg give et eksempel på et vellykket netbaseret samarbejde.

Ud over de officielle evalueringer af de to første år på uddannelsen (Cheesman \& Qvist 2001; Andersen 2002) bygger artiklen på egne erfaringer med MCC, hvor jeg har arbejdet som medplanlægger fra første færd, som vejleder og underviser og også som kritisk iagttager (Cheesman \& Heilesen 2001; Heilesen 2002; Jensen \& Heilesen under udgivelse).

\section{Baggrund: MCC}

Master i Computer-mediated Communication (http://www.mcc.ruc.dk) er en 2-årig uddannelse på deltid (60 ECTS-points i alt), der henvender sig til informationsmedarbejdere, journalister og andre, som har brug for at supplere praktisk formidlingserfaring med en teoretisk baseret viden om nye medier. Den typiske studerende er 35-45 år og har rutine i at deltage $i$ eller lede projekter. Uddannelsen kombinerer seks årlige weekend-internater med et antal netsemi- 
narer (af 4 - 6 ugers varighed) og et større projekt (4 - 5 måneder). Der er altså tale om den karakteristiske danske form for "blended learning", hvor internaterne ud over at lægge op til og samle op på netseminarerne også bidrager med en intens socialisering.

Et netseminar indledes med en række oplæg og øvelser på et weekend-internat, afrundet med igangsætningen af den opgave, de studerende gruppevis skal arbejde videre med i uddannelsens konference- og arkivsystem, BSCW (Basic Support for Coperative Work, se:

http://www.bscw.de). Gruppemødet på internatet er efter vores erfaring vigtigt for at få lavet en opgavefordeling, planlægge forløbet og finde en fælles forståelse af den opgave, der skal løses i løbet af de kommende uger. Det er som bekendt overkommeligt at diskutere på nettet, men det er ganske svært at træffe en beslutning - og vide at den er truffet - uden at se hinanden i øjnene. Med start i efteråret 2003 udbydes imidlertid forsøgsvis seminarer i form af rent netbaserede enkeltkurser, hvor det fællesskab, der opbygges på internatet, forsøges erstattet med en indkøringsperiode på nettet omfattende teknisk instruktion i BSCW samt indledende diskussioner om kursuslitteraturen. Hvad enten det drejer sig om et hybrid- eller et rent netbaseret kursus er opgaven for de studerende at udarbejde et essay, et web-sted eller en PowerPoint-præsentation, som skal belyse et emne, udstukket af den underviser, som har ansvaret for pågældende netseminar. De studerende arbejder udelukkende med dette ene emne i seminarperioden, da det synes at være uhensigtsmæssigt, for ikke at sige umuligt, at få flere aktiviteter til at fungere samtidigt $i$ et netmiljø.

Arbejdet på projektet, der på 2. år udgør masterafhandlingen, begynder så småt i det sene efterår og forløber som hovedaktivitet fra midten af januar og til midten af maj, hvor der skal afleveres en større skriftlig rapport. De studerende har således mindst ét semesters erfaring med at samarbejde i grupper på nettet, når projektet går i gang. Projektet starter officielt i forbindelse med januar-internatet, og i løbet af foråret er der to internater, hvor de studerende fremlægger og diskuterer statusrapporter med vejledere og medstuderende. Hertil kommer en ret omfattende netbaseret vejledning, bestående dels af et par obligatoriske rapporteringer på nettet og dels af en løbende dialog med vejlederen om alt lige fra formelle krav og tekniske problemer til litteratur-, teori- og metodevalg og afprøvning af idéer. Som et eksempel på omfanget kan nævnes, at den gruppe, som omtales nærmere senere i artiklen, i løbet af en 4måneders periode udvekslede 63 diskussionsindlæg, 6 dokumenter og 3 links med vejlederen. Projektemnet er defineret af de studerende i samråd med en vejleder. Mens grupperne på de korte netseminarer i efteråret sammensættes af underviserne, er det i foråret op til de studerende selv at finde sammen i projektgrupper. Trods opfordring til at arbejde sammen i større grupper, understøttet med diverse team-building aktiviteter, vælger en del dog at arbejde alene eller parvis. I løbet af de første tre år har der således på MCC været gennemført $\mathrm{i}$ alt 28 projekter, hvoraf de 16 blev udført af grupper af en størrelse ( 3 - 6 personer), hvor computerstøttet samarbejde begynder at give mening.

\section{At flytte ud på nettet}

MCC er et af de mange nye uddannelsestilbud, der søger at udnytte den fleksibilitet i uddannelsesforløbet, som internettet angiveligt muliggør. Men ved nærmere eftersyn er det nu så som så med frigørelsen fra industrialderens krav om synkronisering og lokalisering. Alene det at blended learning indebærer en (om end begrænset) fysisk tilstedeværelse, betyder, at studiet opdeles i en skemalagt, synkroniseret progression af studieaktiviteter, som griber ind i hverdagsrytmen. I disse aktiviteter er der indlagt yderligere bindinger i form af deadlines på nettet for statusrapporter om studieaktiviteten. De er naturligvis nødvendige for at sandsynliggøre, at de studerende er på rette spor. Men alt i alt er rammerne for et studium som MCC nogenlunde lige så faste som i et konventionelt studium. Fleksibiliteten i vores udgave af netbaseret 
- eller rettere netstøttet - undervisning består i, at den studerende selv kan vælge ugedag og tid på døgnet, hvor han eller hun vil logge på nettet for at deltage i de fælles studieaktiviteter.

Det er måske et lidt uvenligt billede, fordi de frihedsgrader, en netbaseret uddannelse trods alt giver, ofte er afgørende for, om en studerende er i stand til at indpasse et studium i den travle hverdag. Men det tjener som eksempel på, at det er rigtig svært at flytte fra en konventionel uddannelse i murstensomgivelser til en ny form for uddannelse i cyberspace. De fleste undervisere har problemer med at frigøre sig fra det, de kender og er overbeviste om fungerer, og det hjælper ikke, at de værktøjer, der er til rådighed, alle i en eller anden grad opleves som elektroniske versioner af konventionelle værktøjer. E-mail minder således om breve, en diskussionstråd minder om diskussionen i klasseværelset, ressourcearkivet adskiller sig i funktion ikke synderligt fra kompendier og uddelingskopier, streaming video gengiver en forelæsning, om end tilhøreren her kan kontrollere talestrømmen. Opslagstavle, kursusplan, deltagerliste er gentagelser fra den fysiske verden, og e-læringssystemer ynder endda at bruge metaforer hentet fra det fysiske undervisningsmiljø. I den mest fantasiløse form for netbaseret undervisning bliver der simpelthen sat strøm til det (sandsynligvis velfungerende) eksisterende, hvad enten det er et korrespondancekursus eller holdundervisning med en blanding af forelæsninger og diskussioner.

Ambitionen med MCC har imidlertid været højere end blot bevidstløst at remediere ("det samme, bare bedre i det nye medium") problemorienteret projektarbejde. Netop projektarbejde synes at kunne udvikles, så arbejdsgange og samarbejdsformer optimeres til nettets vilkår, og der er desuden god mening i at undervise i computermedieret kommunikation ved hjælp af computermedieret kommunikation. Ud over det faglige indhold får de studerende således praktisk erfaring $i$ at samarbejde i virtuelle miljøer, og det er en kompetence, som givet vil blive efterspurgt allerede i den nære fremtid. Vores valg af software afspejler disse hensyn. BSCW er nemlig et system til edb-støttet samarbejde (CSCW, Computer-Supported Collaborative Work) snarere end til e-læring, som det angiveligt ikke er udpræget velegnet til (Sikkel m.fl. 2001). Brugergrænsefladen i BSCW er modelleret i stil med pc'ens filarkiv (Filhåndtering) med et hierarki af mapper, som hver især kan rumme digitale objekter af alle slags. En mappe kan fx bestå af en arbejdsfil i Word, af en annotation til arbejdsfilen med kommentarer til form og indhold, af andre tråde med diskussioner af relevante emner, af links til diverse web-steder og et bibliotek af pdf-, PowerPoint, gif-filer med mere. I BSCW kan brugeren således indrette sig et virtuelt projektgrupperum, som (inden for systemets muligheder) er skræddersyet til bedst muligt at løse opgaven, mens mange andre systemer af tekniske hensyn vil sprede opgaven ud over de forskellige funktionaliteter (moduler), systemet er sammensat af (filarkiv, diskussionsforum, chat, opslagstavle mm).

En væsentlig opgave for vores studerende har som nævnt været at eksperimentere med arbejdsformer i netmediet. Det har nogle af dem da også gjort, men langt fra alle af de 16 langvarige MCC-projekter med tre eller flere deltagere har benyttet BSCW som det væsentligste kommunikationsmiddel gennem hele projektforløbet, og det har været så som så med den kreative udnyttelse af mediet. Stort set alle har brugt systemet som arkiv og til den obligatoriske dialog med henholdsvis vejleder og opponentgrupper. En del har benyttet det som projektstyringsværktøj på en meget enkel måde. Men meget få grupper er gået helhjertet ind i et netbaseret samarbejde, og når det er sket, har det typisk været i spidsbelastningsperioder op til afleveringer og eksamen, hvor BSCW trods alt har været det mest nærliggende, når det gjaldt om at bevare overblikket og kommunikere hurtigt. Det kommer der et eksempel på senere i artiklen.

Som vejledere har vi kunnet iagttage, at de studerende klart har prioriteret møder i fysiske omgivelser. Nogle af de mest energiske grupper har haft en fast ugentlig mødedag gennem 
hele projektforløbet. Stærkt medvirkende hertil har været, at de studerende fra de tre første MCC-årgange fortrinsvis har været rekrutteret fra Sjælland og derfor har kunnet mødes uden de helt store praktiske problemer. Deltagere fra andre landsdele har rejst til enkelte af disse møder og har ellers forsøgt at kompensere bl.a. gennem telefonmøder, i et enkelt tilfælde professionelt sat op med konferencemikrofon på mødebordet, så den jyske deltager næsten kunne være til stede. Chat, som i øvrigt ikke har været indbygget i vores første BSCW-versioner, har tilsyneladende været benyttet i ret beskedent omfang. Det er nemlig ikke samtidighed så meget som samvær, der tæller. I evalueringerne af MCC-studiet har de studerende bl.a. forklaret:

"BSCW har støttet projektarbejdet godt, men det er urealistisk at forvente, at al samarbejde kunne foregå på denne måde. Face-to-face møderne har varet det mest vardifulde undervejs i forløbet."

"Den [BSCW] supplerer med nye muligheder, men hvis det skal vare optimalt kan teknologien ikke erstatte den gode vante kommunikationsform - face to face. Det er f $f f$ man kommer i dybden og nuancerer diskussionerne." (Andersen 2002).

De studerende er tydeligvis ikke anderledes end deres vejledere eller for den sags skyld udviklere af e-læringssystemer. De tænker endnu forholdsvis traditionelt, også når det gælder samarbejde i nye medier. Specielt de studerende på MCC-uddannelsen kommer ofte med en solid erfaring fra deltagelse i projektarbejde. De ved, hvad der skal til for at gennemføre et projekt. Tid er en knap ressource for dem, og de vælger derfor den enkleste og mest effektive løsning, som er at mødes. Gruppearbejde på nettet er omstændeligt, ikke blot på grund af den altdominerende skriftlighed, men også fordi det som nævnt er svært at opnå og konstatere konsensus eller blot en fælles forståelse, når alt skal på tryk, og indlæggene kommer tidsforskudt med op til dages mellemrum. Når beslutningerne først er truffet, er et system som BSCW til gengæld fremragende egnet som en fælles hukommelse, som overbliksværktøj og som arkiv for projektets historie såvel som for den samling af tekster, links, præsentationer mm., der danner baggrund for den endelige rapport. Alt afhængig af hvor meget deltagerne gør ud af at systematisere materialet, vil projektmapperne udgøre en materialesamling, som de studerende kan have glæde af senere.

Selve studiets nuværende form med dets betoning af betydningen af at mødes inviterer nok ikke til at henlægge alt projektarbejde til nettet. Faktisk må det virke selvmodsigende på de studerende. Fra vejlederside har vi ikke forsøgt at lægge en dæmper på den fysiske mødeaktivitet. Den kan jo tværtimod tolkes som et positivt vidnesbyrd om en modnet brug af e-læring, hvor de elektroniske medier ikke (længere) er en del af budskabet, men kun inddrages i det omfang, de reelt bidrager til at forbedre studiemiljøet. En omlægning af studiet med henblik på at motivere til mere udstrakt brug af netbaseret samarbejde er endnu ikke på tale. Men hvis det tidligere omtalte forsøg med at gennemføre korte enkeltkurser falder heldigt ud, vil det give et fingerpeg om, hvordan vi kan styrke CSCW-komponenten i uddannelsen. Inspirationen til de nye kurser er hentet i det britiske Open University (Salmon 2002), hvor erfaringen er, at det er muligt at skabe et velfungerende socialt rum i netbaseret fjernundervisning ved at afsætte god tid til at opbygge et forpligtende fællesskab, inden man tager fat på det faglige indhold. Et sådant fællesskab er endda fri for de intuitive eller socialt begrundede sympatier og antipatier, som uvægerligt skabes i det fysiske miljø på grundlag af den enkeltes ydre og adfærd. På nettet skaber man sin identitet ene og alene gennem det, man bidrager med til fællesskabet.

En yderligere faktorer, der sikkert spiller ind, er selve software-platformen. Der synes at eksistere et nærmest omvendt proportionalt forhold mellem lethed $\mathrm{i}$ brug og frihedsgrader. I et decideret undervisningssystem som fx Blackboard kan man ret let opbygge en ramme for un- 
dervisningen, som lærere og studerende blot skal udfylde. I et temmelig nøgent CSCWsystem som BSCW er derimod intet givet på forhånd. Til gengæld kan brugerne forme et værktøj præcis til deres behov. Hvis de da mestrer teknikken! Såvel observation af de studerende som kursusevalueringerne viser tydeligt, at der helt op på andet studieår, trods grundig instruktion, forekommer betydelige vanskeligheder med at udnytte softwaren på en hensigtsmæssig måde (Cheesman \& Qvist 2001; Andersen 2002). Og givet et i forvejen krævende studium er det forståeligt, at de studerende undgår at gøre sig livet mere besværligt end højst nødvendigt.

\section{Når det lykkes - et eksempel}

Kogt ned til en enkelt sætning handler projektarbejde om at håndtere kompleksitet. Midlerne til at reducere kompleksiteten er de samme i netbaserede projekter som i konventionelle projekter, nemlig: arbejdsdeling, koordinering og jævnlig reorganisering. Det kan der skrives mange anvisninger på. Men i den aktuelle sammenhæng vil det måske være mere interessant med et indblik i et konkret projekt, som blev vellykket blandt andet i kraft af et velfungerende netbaseret samarbejde.

På de følgende sider skal vi følge "Hard fun"-projektets fire studerende i den sidste uge frem til afleveringen. Projektet handler om at formidle Goethes farvelære til børn vha. en multimedieproduktion. Gruppen har gennem hele projektforløbet sat en ære i at benytte BSCW som samarbejdsredskab, men der har også været holdt en række møder på skift hjemme hos gruppemedlemmerne. I den sidste projektuge bliver der holdt endnu et regulært møde, og den allersidste dag mødes to af gruppemedlemmerne for at udskrive og samle rapporten. Men i det store og hele foregår den endelige redigering af de enkelte kapitler, sammenskrivningen af projektrapporten og den endelige udformning af det tilhørende produkt på nettet.

Hele arbejdsprocessen kan rekonstrueres, fordi gruppen fra første færd har benyttet diskussionsfora (ét pr. uge) til at notere samtlige "begivenheder" i projektet (tilføjelser, ændringer mm). I den hektiske slutfase bliver ugens forum også det vigtigste kommunikations- og koordineringsredskab for gruppens medlemmer. Det kan aflæses alene på mængden af indlæg, som stiger dramatisk, efterhånden som det brænder på:
14.5: 3 indlæg,
15.5: 6 indlæg,
16.5: 10 indlæg,
17.5: 11 indlæg (sidste gruppemøde),
18.5: 24 indlæg,
19.5: 16 indlæg,
20.5: 41 indlæg.

Disse tal er ikke repræsentative for den samlede aktivitet i projektmapperne (hvis øverste niveau gengivet i figur 2). Den omfatter nemlig også oprettelse af et antal nye filer samt adskillige ændringer i og annotationer til eksisterende filer. Teksterne i ugens diskussionsforum handler især om projektstyring og praktiske problemer, mens det er i annotationerne til arbejdsdokumenter og i de tematiske diskussionstråde, at man skal finde den form for forhandling af mening, som vi normalt forbinder med læring i fællesskab (collaborative learning).

Citaterne i det følgende gengiver uddrag af de mange indlæg i den sidste arbejdsuges forum. De er til dels forkortet, sådan at drøftelser af fagligt indhold i rapporten, citater fra tidligere indlæg (antydet med stikord i kantet parentes) samt dele af lange punktopstillinger er skåret væk. Opsætningen er redigeret, idet linjedelingen ikke altid er opretholdt og headeren på de 
enkelte indlæg er sammenstykket af de to sæt oplysninger, der optræder i BSCW. Personnavnene $\mathrm{i}$ headere og tekst er fiktive. Figur 1 viser et lille udsnit af en diskussion (dele af den citeret nedenfor; 18.5).

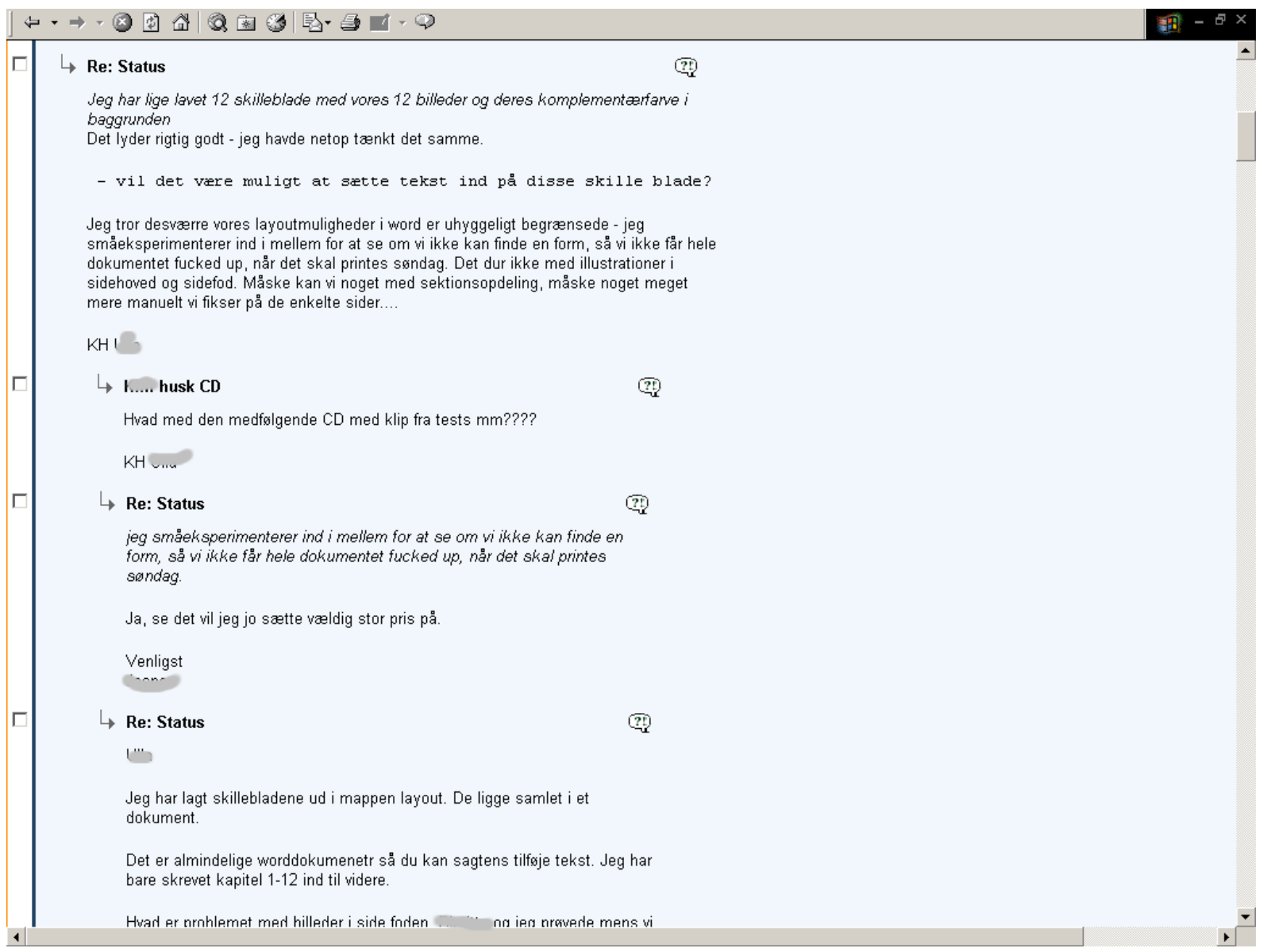

Figur 1: Udsnit af diskussion i “Hard Fun"-gruppens "Uge20”-forum.

Den afsluttende projektuge starter ligesom de foregående uger med et program for ugen og en rapport fra gruppens "indpisker":

Anders 14.5: Uge 20

Indpisker: Anders

Møde: Torsdag 17. maj kl. 10 hos Dorthe

Aflevering: Mandag 21. maj

Anders 14.5: Indledning

... Nu ligger der et næsten færdigt forslag til indledning i manusmappen $i$ rapport-mappen. (...)

\section{Anders 14.5: Manus}

Jeg har flyttet Dorthes analyse-afsnit over i manus-mappen Manus-mappen rummer al tekst der skal indgå i den endelige projektrapport. Her ligger også seneste version af dispositionen i oversigtsform.

\section{Anders 15.5: Brug for en kærlig hånd m.v.}

(...) Litteraturlisten har holdt flyttedag, så den nu bor i manus-mappen

(...) Ud over de nævnte småting mangler vi jo en del, så her følger en hurtig status:

Titelblad - tager jeg

Resumé - tager jeg (...) 


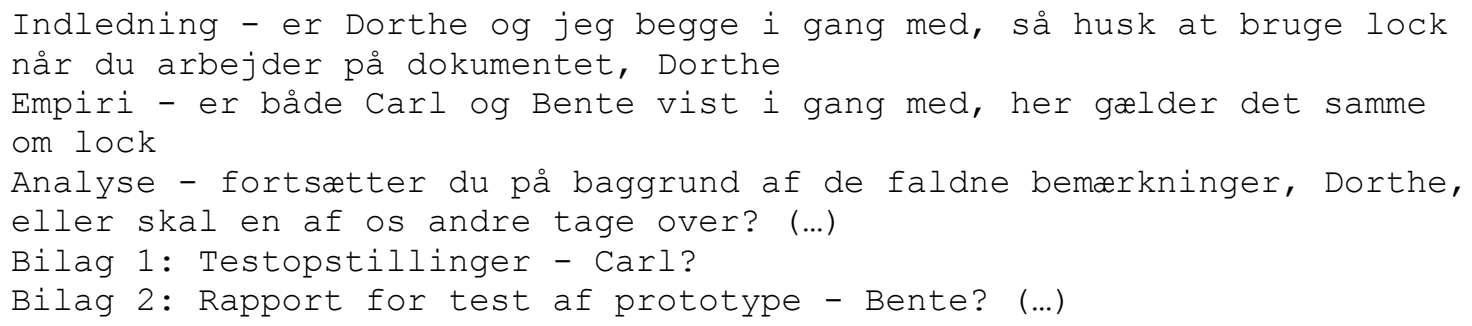

Gruppen har valgt at organisere sig med en "indpisker", en rolle der går på skift mellem gruppens medlemmer. Indpiskeren er ansvarlig for at sikre fremdrift i arbejdsprocessen, og det er også ham, som enevældigt har retten til at reorganisere projektmapperne. Alle sådanne ændringer noteres i det fælles forum. Løbende reorganisering af projektmapperne letter overblikket betydeligt, og det er en af de klare fordele ved at samarbejde på nettet: Man kan hurtigt reorganisere et projekt, så strukturen svarer til de øjeblikkelige behov, samtidig med at alle dokumenter bevares og endda nemt lader sig genfinde gennem mappe-hierarkiet eller ved søgning. "Hard fun" gruppen har meget fin orden i projektmapperne, fordi indpiskeren konstant rydder op og flytter filer derhen, hvor de hører til. Figur 2 viser den overordnede projektmappe (venstre side) samt et udsnit af "rapport"-mappen (til højre).

\begin{tabular}{|c|c|c|c|c|c|c|c|c|c|}
\hline i & $\ulcorner\square$ & $\begin{array}{l}\text { Planlægning m.v. } \\
\text { Tidsplaner og andre generelle ting. }\end{array}$ & & incir & 2001-02-19 & or $D$ & & & $\Delta$ \\
\hline i & $\ulcorner\square$ & $\begin{array}{l}\text { Empiri } \\
\text { Alle feltstudier: Interview med eksperter, såvel som } \\
\text { brugertest. }\end{array}$ & & sing & $2001-03-25$ & $\nabla$ & & & \\
\hline i & $\ulcorner\square$ & Produkt & & $-\mathrm{C}_{\mathrm{r}}$ & $2001-04-05$ & $\cos$ & & & \\
\hline & & $\begin{array}{l}\text { Konkrete emner fra farvelzeren. Udvikling af prototype. } \\
\text { Justering af samme. NB at brugertest ikke er placeret }\end{array}$ & $\ulcorner\square$ & Gammelt & & & & 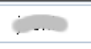 & 2001-04-29 \\
\hline & & her, men i mappen 'Empiri'. & $\ulcorner\square$ & Litteratur & Iser & & & 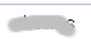 & 2001-05-20 \\
\hline i & $\ulcorner\square$ & $\begin{array}{l}\text { Etik } \\
\text { Materiale ang. opgave til aflevering } 26 \text {. april }\end{array}$ & & $\begin{array}{l}\text { Dokumente } \\
\text { litteraturhen }\end{array}$ & $\begin{array}{l}\text { vor man kan s } \\
\text { nger, der skal }\end{array}$ & & & & \\
\hline i & $\ulcorner\square$ & $\begin{array}{l}\text { Problemformulering } \\
\text { Bidrag og diskussioner i relation til } \\
\text { problemformuleringen for projektet. (lkke }\end{array}$ & $\ulcorner\square$ & $\begin{array}{l}\text { Manus } \\
\text { Dokumente } \\
\text { projektrapp }\end{array}$ & skal indgå i & & & $\therefore$ & $2001-05-20$ \\
\hline & & $\begin{array}{l}\text { problemformuleringer for informationssøgninger, som } \\
\text { placeres i mappen Informations- og }\end{array}$ & ᄃ國 & $\begin{array}{l}\text { Citater } \circ g \\
\text { farvelære }\end{array}$ & netter med & og & 円 & duchono.: & 2001-05-09 \\
\hline & & litteratursøgning). & ᄃ國 & edutainm & & & & $\because$ & 2001-05-01 \\
\hline i & $\ulcorner\square$ & $\begin{array}{l}\text { Litteraturstudier og teoretisk fundament } \\
\text { Diskussioner af litteratur. Bidrag til projektets }\end{array}$ & $\Gamma$ 國 & $\begin{array}{l}\text { Empiri.do } \\
\text { Første tenta }\end{array}$ & udkast... & & & $1=0$ & 2001-05-11 \\
\hline & & $\begin{array}{l}\text { teoretiske fundament. Som viblev enige om I } \\
\text { Svaneke, gæelder det ikke om at teoretisere ud i det }\end{array}$ & $\ulcorner$ 國 & Hypotese & kl. $\cdots$ kom & er.doc & 象 & cosis & 2001-04-30 \\
\hline & & blă, men om at teoretisere operativt. & $\Gamma$ 國 & Hypotese & $c[0.2]$ & & & 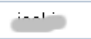 & 2001-05-02 \\
\hline i & $\ulcorner\square$ & $\begin{array}{l}\text { Informations- og litteraturs } ø \text { gning } \\
\text { Projektets litteraturliste samt links til eksternt } \\
\text { materiale. } \\
\text { Til/fra vejleder }\end{array}$ & $\ulcorner$ 國 & $\begin{array}{l}\text { "s k } \\
\text { til is te } \\
\text { Jeg har fjerr } \\
\text { loade. }\end{array}$ & $\begin{array}{l}\text { nentarer til } \\
\text { m prod..doc } \\
\text { illederne for at }\end{array}$ & $\begin{array}{l}\text { mmentarer } \\
\text { lettere at }\end{array}$ & ஹ & -1. & 2001-05-12 \\
\hline i & $\Gamma \square$ & Rapport & ᄃ國 & Produkt_F & es_beskriv & & & 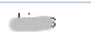 & 2001-05-09 \\
\hline & & $\begin{array}{l}\text { Bidrag til slutrapport. Diskussioner m.v. i relation til } \\
\text { samme, herunder refleksioner over projektets } \\
\text { resultater. }\end{array}$ & & $\begin{array}{l}\text { Beskrivelse } \\
\text { overvejlser } \\
\text { Det indehol }\end{array}$ & $\begin{array}{l}\text { ires produkt, } 0 \\
\text { Ig vi har vaeret } \\
\text { n del billeder }\end{array}$ & $\begin{array}{l}\text { ksperimenter, } \\
\text { underejejs. } \\
\text { vaer tälmodig }\end{array}$ & & & \\
\hline i & $\ulcorner\square$ & Uge $3-20$ & ᄃ國 & Revidere & position & & & 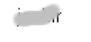 & 2001-03-29 \\
\hline $\mathbf{i}$ & $\ulcorner\square$ & Projektrapport & & $\begin{array}{l}\text { Den versic } \\
2001 .\end{array}$ & 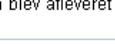 & & & & \\
\hline & & Den færdige projektrapport & Г国 & Skabelon & & & 㑒 & $\operatorname{in}$ & 2001-03-21 \\
\hline i & Г年 & $\begin{array}{l}\text { Uge 21-23 } \\
\text { Aktuelle meddelelser }\end{array}$ & & $\begin{array}{l}\text { Brug denne } \\
\text { indgă } i \text { den }\end{array}$ & lige rapport. H & r der skal & & & \\
\hline $\mathbf{i}$ & $\ulcorner\square$ & Eksamen & & $\begin{array}{l}\text { Overskrift-hi } \\
\text { bruger Mac } \\
\text { denne skab }\end{array}$ & $\begin{array}{l}\text { i. (Undskyld, } \\
\text { ormentlig ikke }\end{array}$ & ved godt at du & & & \\
\hline & & & $\ulcorner$ 國 & $\begin{array}{l}\text { Testmeto } \\
\text { Nu integrere }\end{array}$ & $\begin{array}{l}\text { 0.4] } \\
\text { mpiri-afsnittet. }\end{array}$ & & $\not$ & $\therefore$ & 2001-05-19 \\
\hline & & & Г國 & $\begin{array}{l}\text { Testopsar } \\
\text { Nu integrere }\end{array}$ & $\begin{array}{l}\text { g/testerfarir } \\
\text { mpiri-afsnittet. }\end{array}$ & & & $\because$ & 2001-05-19 \\
\hline & & & $\Gamma$ 國 & udkast til & port til 4.6.n & & $\not ゚$ & cing & 2001-05-09 \\
\hline
\end{tabular}

Figur 2: "Hard Fun"-gruppens overordnede projektmappe (til venstre) og udsnit af "projekt"-mappen (til højre).

Indpiskerens oplæg fremkalder en serie svar over de næste to dage, hvor de øvrige medlemmer påtager sig udestående opgaver samt rapporterer om, hvad de aktuelt er i gang med. Funktionen "Lock" bliver også diskuteret, for den er endnu noget uvant for gruppens medlemmer: Man kan låse et dokument, så andre ikke kan overskrive det, mens man selv lægger 
ændringer ind. Det bliver sommetider til en næsten-tidstro dialog, når gruppemedlemmerne sidder hver for sig og arbejder, her i en sen nattetime:

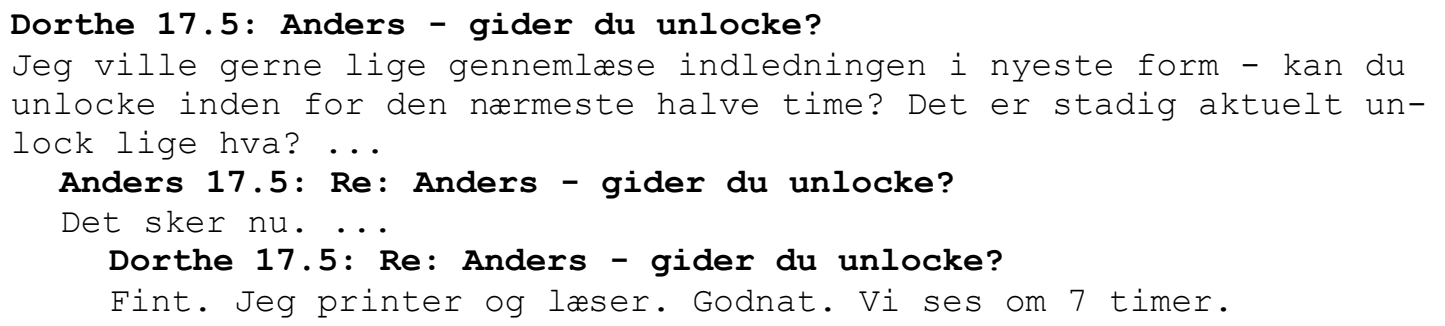

Og på et tidspunkt går det naturligvis galt:

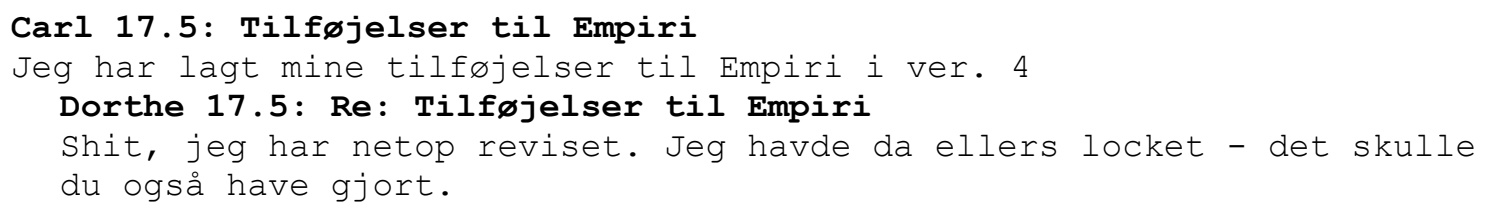

På grundlag af tilbagemeldingerne samler indpiskeren igen op på arbejdsopgaverne og indskærper, at alle bruger versionerings-faciliteten, så man præcis kan følge hvert enkelt dokuments historik og eventuelt vende tilbage til ældre versioner af filer, der er blevet ødelagt som i eksemplet ovenfor. Som ugen skrider frem, laves der status dagligt eller mindst hver anden dag:

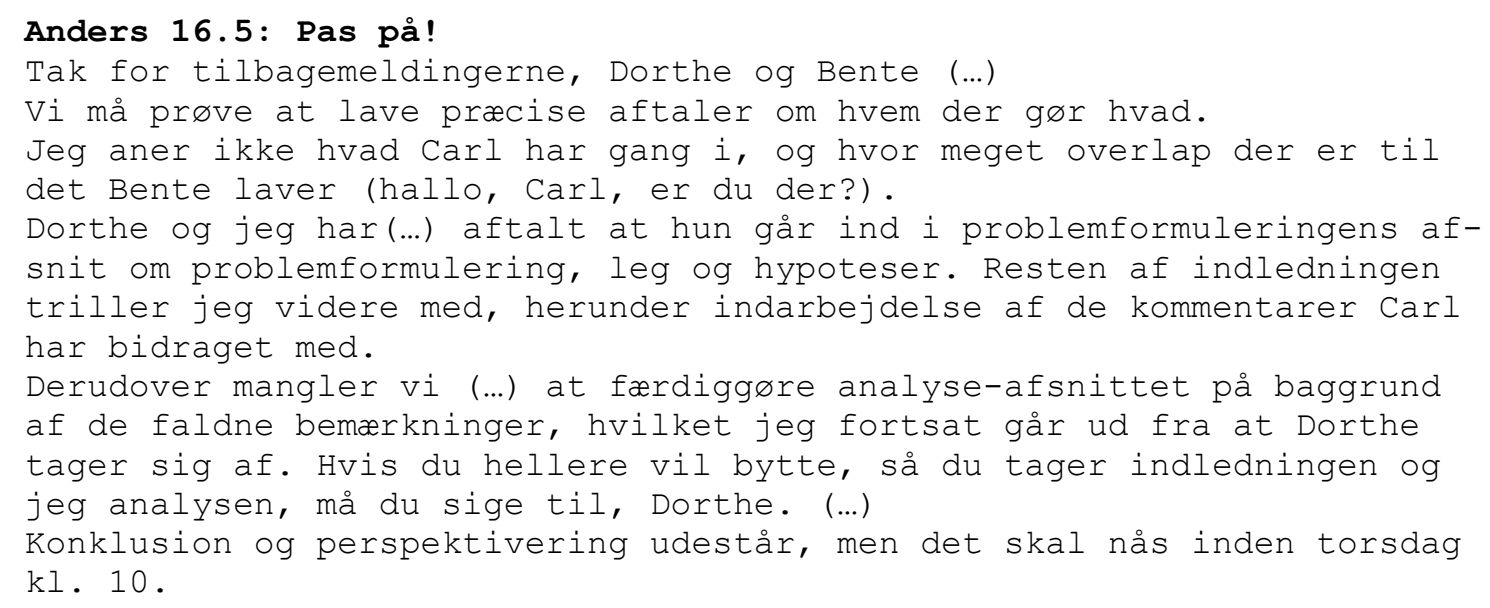

\section{Anders 16.5: Meddelelse fra din bibliotekar}

For at alle nu er helt med på hvordan tingene kører i manus-mappen, så tager vi den lige skåret i pap:

Alle nye versioner af dokumenter lægger man som (ja, gæt selv!) nye versioner. Det er jo bl.a. derfor vi bruger BSCW.

Det betyder at hvis man har gjort bemærkninger i et dokument som en anden har lavet, så bruger man revise til at lægge en ny version af dokumentet. I feltet med changes in version [no.] skriver man hvad man har gjort ved dokumentet. F.eks. "Anders' kommentarer indsat" (eksempel fra analyse-dokumentet). (...)

"Carl" har på dette tidspunkt været tavs et stykke tid, og det irriterer tydeligvis de andre. Gensidig tillid er grundlæggende for alt samarbejde på nettet, og den opbygges først og fremmest gennem nærvær. I senere citater ses, hvordan en anden deltager omhyggeligt forbereder eller forklarer selv ret kortvarige fravær. Carl vender dog tilbage samme dag med en undskyldning til de andre: 


\title{
Carl 16.5: Jeg er her stadig
}

Beklager mit fravær derude.

Men jeg har været "nede" på flere måder. Den mest håndgribelige er at vores netadgang har været nede. Den anden har jeg kun lyst til at beskrive som "nede" på dette sted.

Men jeg er på. Jeg arbejder videre med empiriafsnittet(...)

Efter hver af de hyppige opsamlinger indløber der statusrapporter fra gruppemedlemmerne. De egentlige diskussioner af indhold bliver som nævnt anbragt i tilknytning til de filer, der arbejdes på. I rapporterne indgår jævnligt bemærkninger, som sætter arbejdet på nettet med dets upersonlige timing ind i den dagliglivs-kontekst, som er den enkelte studerendes virkelighed.

\author{
Bente 16.5: Småtilretninger \\ Jeg har lavet nogle småjusteringer rundt omkring. \\ - Det ene som en note til "Analyse"-dokumentet \\ - Finjusteringer af bilag 2-4 \\ - Bilag 5 har jeg enevældigt prøvet at bringe lidt mere struktur i, \\ protester modtages gerne. \\ - Jeg har kommenteret nogle af kommentarerne til "Empiri"-dokumentet.
}

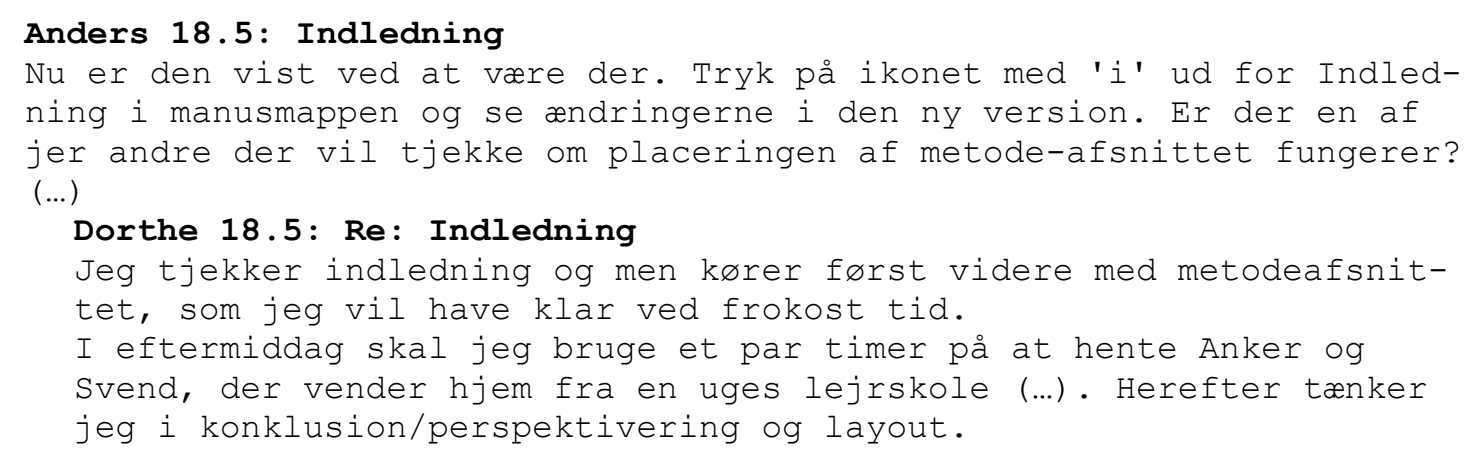

Med mellemrum opstår der større diskussioner, som fx den følgende, der løber over en enkelt dag (teksten i de enkelte indlæg er stærkt forkortet; udsnit gengivet i figur 2). Trådningen er ikke konsekvent: Folk svarer på kryds og på tværs af indlæg, så det går åbenbart stærkt med at skrive. Men den manglende systematik generer tilsyneladende ikke deltagerne, som også bryder alle regler for navngivning af indlæg og kravet om enkelthed i indlæg (ideelt ét emne pr. indlæg) i en livlig meningsudveksling, som faktisk får styr på nogle problemer:

\section{Anders 18.5: Status}

Jeg kaster mig over det empiri-afsnit som Carl uploadede i nat. Dorthe arbejder sideløbende på nogle bidrag om testmetoder til det samme afsnit. Kan I andre ikke lige melde ind hvad I hver især arbejder med lige nu?

\section{Carl 18.5: Re: Status}

Jeg har lige lavet 12 skilleblade med vores 12 billeder og deres komplementærfarve i baggrunden. Lige nu fedter jeg med andre illustrationer. (...)

Dorthe 18.5: Re: Status

(...) - vil det være muligt at sætte tekst ind på disse skille blade?

Jeg tror desværre vores layoutmuligheder i word er uhyggeligt begrænsede - jeg småeksperimenterer ind i mellem for at se om vi ikke kan finde en form, så vi ikke får hele dokumentet fucked up, når det skal printes søndag. (...)

Dorthe 18.5: Carl husk CD

Hvad med den medfølgende CD med klip fra tests mm???

Anders 18.5: Re: Status

["jeg småeksperimenterer (...) ] 


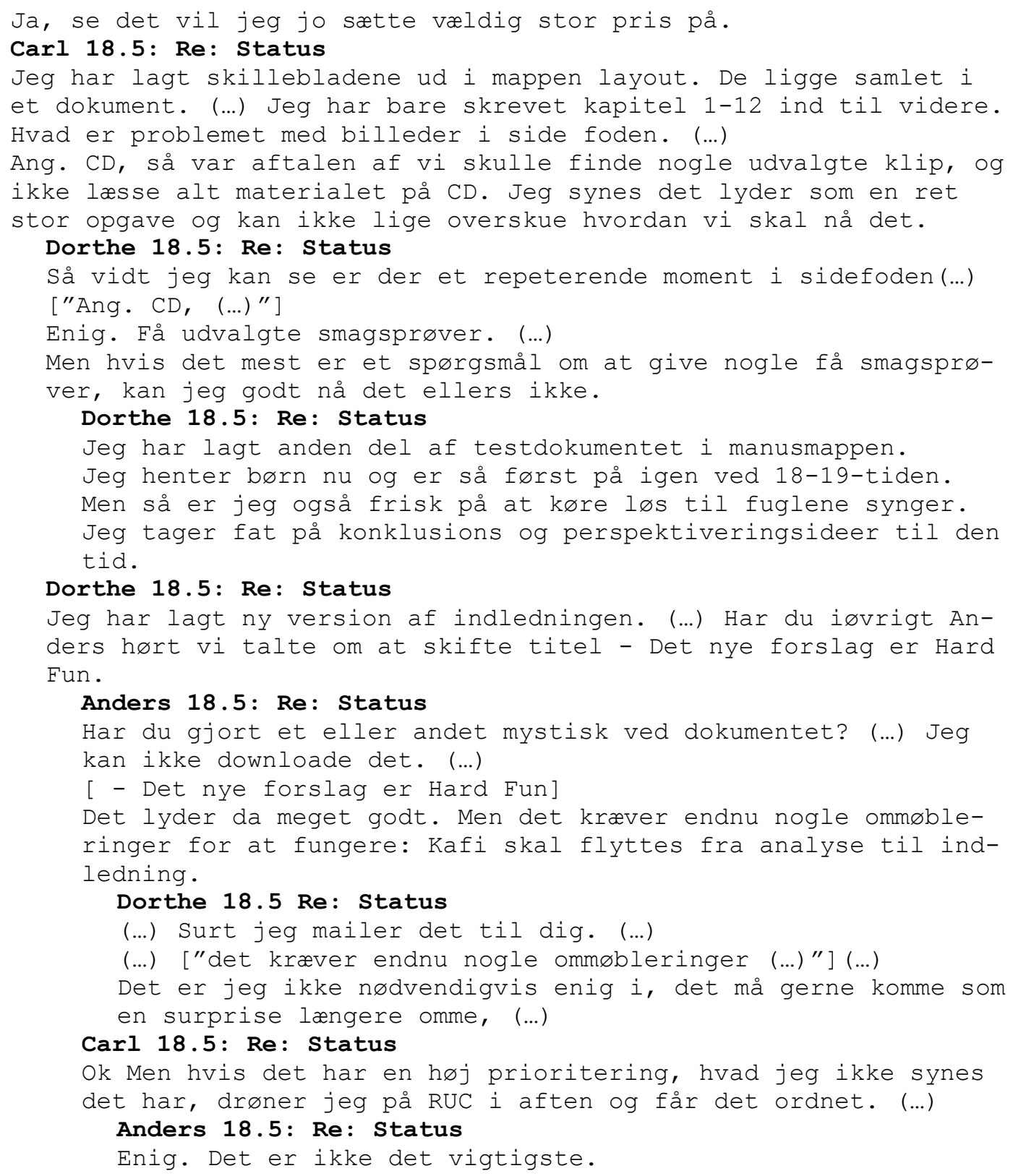

Således fortsætter snakken, mens de fire gruppemedlemmer slider i det på alle døgnets tidspunkter, både hjemmefra og fra deres arbejde, dvs. fra Albertslund, Allerød, Gentofte, København N og K, Hørsholm og Roskilde. De sidste tre dage, hvor samarbejdet udelukkende foregår på nettet, lykkes det dem at enes om færdige versioner af de enkelte kapitler, de får layoutet rapporten og skrevet den igennem en sidste gang, og de får lavet forside, resumé, skilleblade, indholdsfortegnelse og litteraturliste, det sidste efter en mindre krise, da det kommer frem, at flere vigtige værker er faldet ud. Kun den sidste eftermiddag mødes, som nævnt, to gruppemedlemmer for at få fremstillet det nødvendige antal eksemplarer af rapporten. Det bliver i øvrigt en sindsoprivende eftermiddag, som det fremgår af de løbende situationsrapporter til de to fraværende gruppemedlemmer:

\section{Anders 20.5: Murfys lov}

Hvis noget kan gå galt, så går det galt.

Den store, dyre og på alle måder ellers fede farvelaserprinter er gået død, og samtlige mine genoplivningsforsøg er slået fejl. Den beder nu også så nådigt om at jeg tilkalder en tekniker, så det må jeg jo hellere gøre, men han kommer nok ikke inden vi skal aflevere.(...) 
Anders 20.5: Murfys lov 2

Hvis alt kan gå galt, så går det galt.

$\mathrm{Nu}$ er sort-hvid-kopimaskinen også stået af. Jeg nåede kun at lave fire

sort-hvide eksemplarer. (...)

Men alt endte alligevel (næsten) lykkeligt. To uger senere leverede gruppen et godt forsvar af projektrapporten. Ud over det faglige indhold var udbyttet af projektarbejdet både færdigheder i at gennemføre et projekt $i$ et netmiljø og opøvelse af en intenst forhandlende arbejdsform, som manifesterede sig sprudlende også ved eksamensbordet, hvor hverken censor eller eksaminator helt formåede at følge med. Man kan så diskutere, om eksamenssituationen egner sig til helt fri diskussion. Men lidt tankevækkende er det naturligvis, at de studerende oplever, at eksamensformen er ude af trit med de processer, som har frembragt eksamensgrundlaget:
"Jeg var lidt skuffet over at både eksaminator og censor var så bundet af den traditionelle eksamenform. De spillede da deres roller meget godt, og de var begge to bestemt også valdig flinke, men jeg sad og følte det lidt som var vi alle sammen del af et skuespil. Det havde varet rart med en mere åben dialog, sådan ping-pong. I øvrigt savnede jeg bagefter et svar på hvorfor vores projekt ikke var til 13. Egentlig er jeg enig $i$ at det var det ikke, men omvendt kan jeg ikke vide om mine kriterier for denne bedømmelse svarer til eksaminators og censors kriterier. Vi fik ikke at vide eksakt hvad vi kunne have gjort bedre”. (Cheesman \& Qvist 2001).

Projekttitlen Hard Fun henviser til gruppens produkt, som er et undervisningsprogram. Men det spiller også underfundigt på oplevelsen af det lange projektforløb, hvor gruppens medlemmer valgte at skabe deres helt egen arbejdsform ud fra de muligheder, som netmediet og den givne software kunne tilbyde. Det er ikke nogen enkel sag både at skulle gennemføre et projekt og udvikle værktøjerne til at gøre det med. Vi har derfor kun set et beskedent antal forskellige måder at gribe sagen an på, men nok til at indse at der ikke kan anvises én bestemt standardløsning, og at det heller ikke er sandsynligt, at vi får indført rent netbaseret projektarbejde på uddannelsen. I stedet går udviklingsarbejdet nu på at finde den passende blanding af ansigt-til-ansigt- og netbaseret samarbejde, sådan at netmediet bliver en optimal hjælp og ikke en hæmsko.

\section{Litteratur}

Andersen, Nina Blom. Evaluering af 2. år på MCC-uddannelsen. CNCL Working Paper 4/2002. Institut for Kommunikation, Journalistik og Datalogi, Roskilde Universitetscenter, 2002. Online: <http://www.cncl.ruc.dk/pub/WP-04.pdf > (downloaded 5.8.2003).

Cheesman, Robin \& Mette Qvist. Evaluering af 1. år på MCC-uddannelsen. CNCL Working Paper 2/2001. Institut for Kommunikation, Journalistik og Datalogi, Roskilde Universitetscenter 2001. Online: <http://www.cncl.ruc.dk/pub/WP-02.pdf > (downloaded 5.8.2003).

Cheesman, Robin \& Simon B. Heilesen. "Using CSCW for problem-oriented teaching and learning in a net environment". In: European Perspectives on Computer-Supported Collaborative Learning. Proceedings of the first European Conference on ComputerSupported Collaborative Learning. Eds. Pierre Dillenbourg, Anneke Eurelings \& Kai Hakkarainen. Maastricht: Universiteit Maastricht, 2001. 708-709. Online-version af uforkortet manus: < http://www.ruc.dk/ simonhei/docs/papers/csc12001.pdf> (downloaded 14.8.2003)

Heilesen, Simon. " CSCW som grundlag for distribueret netbaseret undervisning og læring". I: Uddannelse, laering og IT. 26 forskere og praktikere gør status på området. København: Undervisningsministeriets Forlag, 2002.79 - 86. Online: < http://www.it- 
strategi.uvm.dk/frame/article/article.php3?section=publikationer\&id=59\&type=artikler \&word=heilesen $>$ (downloaded 14.8.2003).

Jensen, Sisse Siggaard \& Simon B. Heilesen. "Time, place and identity in project work on the net". In: Computer-Supported Collaborative

Learning in Higher Education. Ed. Tim Roberts. Under udgivelse (Idea Group 2004).

Salmon, Gilly. E-tivities : the key to active online learning. London: Kogan Page, 2002.

Sikkel, Klaas, Lisa Gommer \& Jan van der Veen: "A cross-case comparison of BSCW in different educational settings". In: European Perspectives on Computer-Supported Collaborative Learning. Proceedings of the First European Conference on ComputerSupported Collaborative Learning. Eds. Pierre Dillenbourg, Anneke Eurelings \& Kai Hakkarainen. Maastrich; Universiteit Maastricht, 2001. 553 - 560. 